\title{
Evaluation of fertility, hatchability and egg quality of indigenous chicken at different agro-ecologies of Sidama Region, Ethiopia
}

Legesse Yotona Tunsisa ( $\sim$ legesetunsisa52@gmail.com )

Southern Agricultural Research Institute

Kefyalew Berihun

Hawassa University College of Agriculture

\section{Research Article}

Keywords: Agro-ecology, Egg quality, Fertility, Hatchability, Indigenous chicken

Posted Date: January 27th, 2022

DOI: https://doi.org/10.21203/rs.3.rs-1250626/v2

License: (c) (i) This work is licensed under a Creative Commons Attribution 4.0 International License.

Read Full License 


\section{Evaluation of fertility, hatchability and egg quality of indigenous chickens in different agro-ecologies of the Sidama Region, Ethiopia}

Legesse Tunsisa ${ }^{1}$ and Kefyalew Berihun ${ }^{2}$

${ }^{1}$ Southern Agricultural Research Institute Hawassa Agricultural Research Center

${ }^{2}$ Hawassa University College of Agriculture, Department of Animal and Range Sciences

Corresponding author: Legesse Tunsisa, Southern Agricultural Research Institute, Hawassa, Ethiopia, email: legesetunsisa52@gmail.com

\section{Abstract}

Poultry is one of the most important subsectors of livestock, supplying a cheap source of good quality animal protein in the form of meat and eggs. This study was conducted to assess egg fertility, hatchability and egg quality parameters of indigenous chickens in the Hulla, Aleta Wondo and Dale districts, representing highland, midland and lowland agroecologies, respectively.

Six kebeles (two kebeles from each district) were purposively selected based on a lower distribution of exotic chickens. A total of 750 eggs of indigenous chicken were collected from three different agro-ecologies, 450 eggs were used for fertility and hatchability evaluation, and 300 eggs were used for internal and external quality analysis. The collected data were analyzed using SPSS version 20 and SAS version 9.0 packages.

The results indicated that agroecology has no significant effect on the fertility and hatchability of indigenous chicken eggs. The values of egg weight, egg length, shell weight, yolk weight, and yolk diameter and albumen weight of eggs collected from midland were higher than those of eggs from highland and lowland areas. However, the highest values for albumen height, yolk height and Haugh unit were observed on eggs collected from highland agroecology.

In conclusion, agroecology has no effect on the fertility and hatchability of indigenous chicken eggs. However, agroecology significantly affects the internal and external egg quality of indigenous chicken eggs. Therefore, the storage condition and duration of storage need consideration to maintain the external quality of eggs.

Key words: Agro-ecology, Egg quality, Fertility, Hatchability, Indigenous chicken 


\section{INTRODUCTION}

\section{Background Information and Justification}

Livestock is an important subsector of agriculture, and poultry is one of the most important subsectors of livestock, supplying a cheap source of good-quality animal protein in the form of meat and eggs (Nure Hasin, 2018). In Ethiopia, the term poultry is almost synonymous with chicken. Other poultry species, such as guinea fowl, geese, turkeys, and ducks, are not common in the country. Poultry production offers considerable opportunities in terms of generating employment opportunities, improving family nutrition, empowering women (especially in rural areas), and ultimately ensuring household food security. Extensive scavenging poultry production is often the domain of poor women. Reasons include that it requires little initial investment and that it does not usually conflict with women's other household duties (FAO, 2019).

Fertility and hatchability are major parameters of reproductive performance that are most sensitive to environmental and genetic influences (Stromberg, 1975). Fertility refers to the percentage of incubated eggs that are fertile, while hatchability is the percentage of fertile eggs that hatch. Egg quality is a factor that contributes to the better economic price of fertile and table eggs (Kocevski et al., 2011). The overall quality of an egg can be discussed under two broad categories, namely, external and internal quality (Monira et al., 2003). The external quality of the egg is determined by features such as the egg weight and shape of the egg, shell thickness, and strength of the shell (Bain, 2005). From the point of view of consumers, egg weight is the most important quality trait (Adeogun and Amole, 2004; Dudusola, 2010). Shell strength is important not only for producers but also for consumers. Obtaining high eggshell quality is important for both table egg and hatching egg purposes. Consumers have come to expect uniform, strong shelled eggs, and for hatching purposes, eggs that have a strong shell will be more likely to produce a healthy chick (Grignon 2016). The internal quality is measured based on the quality of the albumen as indicated by the Haugh units (HU), the relative size of the various internal components such as weight of yolk, yolk color and the integrity of the shell membrane. Several studies have examined egg quality in chickens (Ahmedin and Mangistu 2016; Yonas et al., 2019; Aberra 2019; Welelaw 2018). In addition, the type of incubation influences the 
hatchability of eggs and the production of viable chicks. Most farmers in Ethiopia hatch their eggs by a natural incubation method using broody hens to incubate eggs and rear chicks (Meseret 2010 and Addisu et al., 2013).

Different studies have been performed on the egg quality, fertility and hatchability of local chickens. However, there is a lack of sufficient and consistent information on the effect of different agro-ecologies on the egg quality, fertility and hatchability of local chickens in the study areas. Thus, this study was conducted with the following objectives to fill the gap discussed.

\section{Objectives}

To evaluate the effect of agroecology on the fertility and hatchability of indigenous chickens in the Sidama region of Ethiopia

To determine internal and external quality parameters of indigenous chicken eggs collected from different agro-ecologies of the study area

\section{METHODOLOGY}

\section{Description of study area}

This study was conducted in three districts of the Sidama Regional State, namely, Hula, Aleta Wondo and Dale, representing high land, midland and lowland, respectively.

Hula

Hula District is located at a distance of $91 \mathrm{~km}$ from Hawassa and $366 \mathrm{~km}$ away from Addis Ababa. The district is located at longitudes and latitudes of $6^{\circ} .41^{\prime}-6^{\circ} .61^{\prime} \mathrm{N}$ and $38^{\circ} .44^{\prime}-38^{\circ} .70^{\prime} \mathrm{E}$, respectively, and 1201 to 3000 masl elevation. It received a mean annual rainfall of 700-1200 $\mathrm{mm}$ with an average annual temperature of $11-180^{\circ} \mathrm{C}$. The total population of the district is 80,464 (Hula district administration office, 2015). The total livestock population of Hula district is 15,456 cattle, 2,215 sheep, 1,056 goats, 769 horses, 456 donkeys, and 3,422 poultry (Hula district livestock and fishery office, 2019). The main agricultural activities of the district are livestock production, enset plantation and cereal crop production. 


\section{Aleta Wondo}

Aleta wondo district is one of 36 districts in the Sidama Regional State. It is located at a distance of approximately $64 \mathrm{~km}$ from Hawassa and $339 \mathrm{~km}$ from the capital city Addis Ababa. It is situated in the coordinates of $6035^{\prime}$ to $6040^{\prime}$ north latitude and $38025^{\prime}$ to $38030^{\prime}$ east longitudes. Mean annual temperature ranging from $10^{\circ} \mathrm{c}$ to $24^{0} \mathrm{c}$. Elevation ranging from 1700 to $2500 \mathrm{masl}$. The average annual rainfall of the district ranges from $900 \mathrm{~mm}$ to $1400 \mathrm{~mm}$ (Aleta Wondo District report, 2013/14). Aleta wondo district borders Dare to the south, Chuko to the west, Dale and Wonsho to the west and Bursa and Hulla to the east. The livestock population is estimated to be 138,251 cattle, 39,211 sheep, 22,421 goats, 3918 horses, 8586 donkeys, 168 mules and 169,256 poultry (Aleta Wondo District Livestock and Fishery Report 2018). The main agricultural practices in the areas include coffee plantations, inset plantations, maize and cereal crop production, cattle fattening, apiculture, vegetable production and fruit production.

Dale

Dale District is one of the 36 districts of the Sidama Regional State. The district is located on Hawassa to Moyale main road at $45 \mathrm{~km}$ from Hawassa and $320 \mathrm{~km}$ from the capital city Addis Ababa, and situated with latitude of $6^{\circ} 39^{\prime} 20^{\prime \prime}-6^{\circ} 50^{\prime} 28^{\prime \prime}$ North and longitude of $38^{\circ} 18^{\prime} 12^{\prime \prime}$ 39³1'30" East. Its elevation ranges from 1200-3200 masl. The annual rainfall of the Dale district ranges from $1300-1900 \mathrm{~mm}$, and the annual temperature varies from $180^{\circ} \mathrm{C}$ to $20^{\circ} \mathrm{C}$ (DWARDO, 2015). The main agricultural activity of the district is livestock production, enset plantation, coffee plantation and cereal crop production.

\section{Protocol of the experiment}

The experiment had two parts. The first part was fertility and hatchability evaluation. For this test, farmers who owned at least one cock of local chicken in his flock were selected during survey work. From those selected households, one hundred fifty eggs of local chickens were collected from each agroecology and transported to Hawassa University Agricultural College, School of Animal and Range Sciences. Eggs were individually cleaned using pieces of clothes treated with savlon before setting. Incubation was conducted according to the guidelines of the incubator's manufacturer. Then, candling was performed two times (day seven and day 
fourteen). Data on the number of eggs set, number of eggs that were fertile, total number of chicks hatched, and number of embryos that died were recorded.

Fertility $(\%)=\frac{\text { No.of fertile eggs }}{\text { Total No.of eggs set }} * 100$

Hatchability percent from fertile eggs $=\frac{\text { No.of chicks Hatched }}{\text { Total No.of fertiled eggs }} * 100$

Hatchability percent from total eggs $=\frac{\text { No.of chicks Hatched }}{\text { Total No.of eggs set }} \quad * 100$

The second part was internal and external egg quality evaluation. This study was conducted at Hawassa University Agricultural College, School of Animal and Range Sciences, poultry laboratory. One hundred eggs were collected from each agroecology (a total of three hundred eggs were used for internal and external quality evaluation). Care has been given that eggs collected should be laid from local chicken breeds (eggs collected from farmers who own only local chickens). The eggs stored for less than five days were collected, and laboratory analysis was conducted as soon as the eggs reached the laboratory.

External egg quality traits

Egg weight and shell weight were measured using a digital balance (gm). Egg length, egg width and shell thickness were measured using a digital caliper $(\mathrm{mm})$. Shell weight was measured after it was dried in an oven for 24 hours (Khatkar et al., 1994). The shell thickness was measured using digital calipers at different points (center, broad and narrow ends), and the calculated average value was used for analysis (Mohammed et al., 2005). In addition, the eggshell ratio and egg shape index were computed using the following formula.

Shell weight $(\%)=\frac{\text { Dry shell Weight }}{\text { Egg Weight }} * 100$

Egg shape index $(\%)=\frac{\text { Width of egg }}{\text { Length of egg }} * 100$ (Van den Brand et al., 2004).

\section{Internal Egg Quality}

For the internal quality traits, the eggs were broken into a flat surface. Thick albumen and yolk heights were measured using a tripod micrometer. The thick albumen height (AH) was measured 
at its widest part at a position half way between the yolk and the outer margin. Yolk height was measured at the center part of yolk. The yolk was carefully separated from the albumen. Albumen and yolk weights were determined by weighing with an electronic sensitive balance separately (gm). The yolk color was determined using the Roche Color Fan (Roach scale), which contains 15 scales with a standard colorimetric system. Individual Haugh units (HU) were calculated from the two parameters height of albumen (AH) and egg weight (EW) (Haugh, 1937) using the formula.

$$
\mathrm{HU}=100 \log \left(\mathrm{AH}-1.7 \mathrm{EW}^{0.37}+7.6\right)
$$

where $\mathrm{HU}=$ Haugh unit, $\mathrm{AH}=$ albumen height in millimeters, and $\mathrm{EW}=$ egg weight in grams.

Estimate YR and AR were used the following formula:

$$
\begin{aligned}
& \mathrm{YR}=\frac{\text { Yolkweight }}{\text { eggweight }} * 100 \\
& \mathrm{AR}=\frac{\text { Albumen weight }}{\text { Eggweight }} * 100
\end{aligned}
$$

Yolk index $=\frac{\text { Yolk Height }(\mathrm{mm})}{\text { Yolk Diameter }(\mathrm{mm})} * 100$

\section{Statistical analysis}

The laboratory data for fertility and hatchability were analyzed by crosstabs among agroecologies in descriptive statistics of SPSS V.20.0. Other parameters, such as external and internal egg quality and correlations among egg quality parameters, were analyzed using the general linear model (GLM) procedure of SAS (Version 9.0). Mean comparisons were conducted using Duncan's multiple range test. Values were considered significant at the 5\% level of significance.

\section{RESULTS AND DISCUSSIONS}

\section{Fertility and hatchability}

The fertility and hatchability results of scavenging indigenous chickens are shown in Table 1. There was no significant variation among agro-ecologies in the egg fertility percentage of indigenous chickens. This implies that agroecology has no influence on the fertility of scavenging indigenous chicken eggs. The result in the current study is in line with the study by 
Ahmedin and Mangistu (2016), who reported a fertility of $74.45 \%$ on rural chickens in the Gorogutu district of Eastern Hararghe. A higher value of fertility (81.1\%-100\%) was reported by Halima (2007) in different agro-ecologies of Northwest Ethiopia, and 95.6\% and 98.9\% was reported by Getnet et al. (2020) on eggs of Tilil and unimproved Horro chickens reared under intensive management. The highest value obtained might be observed due to the variation in the production system. The fertility percentage of indigenous chicken eggs in the current study was higher than the values reported by Meseret (2010) in the Gomma district of the Jimma Zone. The result on hatchability percentage in the current study is in agreement with the report by Mbuthia et al. (2007), who reported that $82.8 \%$ hatchability was recorded for indigenous chickens in Kenya.

There was no significant difference in hatchability on the total egg basis of indigenous chicken eggs among all studied agro-ecologies $(p>0.05)$. The result on hatchability percentage $(63.1 \%)$ in the current study is in agreement with the findings of Tadelle (2003) and Ahmedin and Mangistu (2016), who reported $68.8 \%$ and $64.45 \%$, respectively, with no significant difference in hatchability percentage of Ethiopian indigenous chicken in different agro-ecologies. The finding of the current study is in agreement with the range given by Halima (2007), who reported hatchability of indigenous chickens between $46.2 \%$ and $73.3 \%$. The finding of the present study is lower than the result of Gebreegziabher (2016), who reported total egg basis hatchability of $83.6 \%$ in the highlands and $74.1 \%$ in the midland agroecology of the Wolaita Zone.

The results of the current study revealed that agroecology has no impact on hatchability on the fertile egg basis of indigenous chicken eggs ( $p>0.05$ ). In agreement with current findings, Getnet et al. (2020) reported $81.0 \%$ and $88.9 \%$ hatchability on fertile egg basis for Horro and Tilil local chickens, respectively. Additionally, the findings of the current study are in line with the results reported by Ahmedin and Mangistu (2016), who reported hatchability values on a fertile egg basis of $81.91 \%, 81.99 \%$ and $93.93 \%$ for highland, midland and lowland agroecologies, respectively ( $>00.05)$. Fisseha et al. (2010) reported average hatchability values of indigenous chickens of $82.6 \%, 78.9 \%$ and $89.1 \%$ at Bure, Fogera and Dale, respectively, which is also in good agreement with the present study.

Table 1. Effect of agroecology on the fertility and hatchability of scavenging indigenous chickens 


\begin{tabular}{|c|c|c|c|c|c|c|}
\hline \multirow[t]{2}{*}{ Parameters } & \multicolumn{3}{|c|}{ Agro-ecology } & \multirow[t]{2}{*}{ Overall } & \multirow[t]{2}{*}{ Chi-square } & \multirow[b]{2}{*}{$P$ value } \\
\hline & Highland & Midland & Lowland & & & \\
\hline Fertility (\%) & 76.0 & 78.7 & 79.9 & 78.17 & 0.645 & 0.724 \\
\hline $\begin{array}{l}\text { Hatchability on total } \\
\text { egg basis }(\%)\end{array}$ & 61.0 & 63.0 & 65.4 & 63.1 & 7.217 & 0.125 \\
\hline $\begin{array}{l}\text { Hatchability on } \\
\text { fertile egg basis }(\%)\end{array}$ & 89.2 & 80.9 & 82.2 & 84.1 & 3.321 & 0.190 \\
\hline
\end{tabular}

\section{External and internal egg quality traits}

\section{External egg quality traits}

The external egg quality traits in different agro-ecologies are presented in Table 2. The results indicated that values for egg weight and egg length in midland were significantly higher than lowland and highland, whereas values of egg weight and length in highland is lower than values lowland agro-ecology. Egg weight is highly influenced by hereditary and environmental factors (Sekeroglu \& Altuntas 2009). Environmental factors in terms of the age of hens, body size, diet, water intake, temperature, humidity and management practices may contribute to the variability observed in the results (Isidahomen et al., 2013). The result on egg weight and length in the current study is in agreement with the finding of Aberra (2018), who reported an average egg weight of 43.9 grams on indigenous chickens. Similarly, the results of Markos et al. (2017) and Getnet et al. (2020) are in line with the findings of the present study. In their results, they reported an average egg weight of $40.56 \mathrm{~g}$ for different indigenous ecotypes, $43.5 \mathrm{~g}$ for Horro chickens and $42.3 \mathrm{~g}$ for Tilil chickens. However, Halima (2007) and Ahmedin and Mangistu (2016) reported lower values than the current study egg weights (37.38 $\mathrm{g}$ and $45.75 \mathrm{~g}$, respectively) for indigenous chicken ecotypes of Ethiopia. Average egg weights of $49.79 \mathrm{~g}$, $48.21 \mathrm{~g}$ and $41.32 \mathrm{~g}$ were reported on nacked neck, normal and dwarf strains of Tswana indigenous chickens (Kgwatalala et al. 2016), which is in agreement with the present study. 
Inconsistently higher egg weight was given by Madalena et al. (2019) on different indigenous chicken breeds of Portugal.

The results indicated that agroecology in the study areas had no effect on the shape index of indigenous chicken eggs ( $p>0.05$ ). In agreement with the current study, Aberra (2018) revealed a shape index value of 72.7 for indigenous chickens reared under a traditional management system in the Benchi Maji zone of southern Ethiopia. Similarly, the values in agreement with the current study were given by Veena et al. (2015), who reported shape index values of 72.10 during winter and 71.99 during summer on indigenous chickens of Andhra Pradesh. Hussain et al. (2013) reported an average shape index value of 80.40 on indigenous chickens of Pakistan, which is much higher than the result of current findings. Nedeljka and Kocevski (2006) suggested that the shape index is influenced by season, genetic factors and age group of birds. Eggs are categorized into three shape groups: Sharp $(<72)$, normal $(72-76)$ and round $(>76)$. As this classification, the results of the current study show that eggs of indigenous chickens are classified as normal eggs regardless of other factors. The shape index is an important factor for characterizing species of birds (Song et al., 2000), as well as an indicator of egg quality (Mueller, et al., 1960) and is very important for chick survival (Lundberg and Vaisanen 1979). Egg shape is an important parameter in commercial systems. Sharp eggs and round eggs do not fit well in egg cartons; therefore, they are much more likely to be broken during shipment than eggs of normal shape (Sarica and Erensayin, 2009).

The study indicated that agroecology has a significant effect on the shell weight of indigenous chicken eggs $(\mathrm{p}<0.05)$. Accordingly, shell weight is highest $(4.38 \mathrm{gm})$ in midland agroecology and lowest $(3.70 \mathrm{gm})$ in highland agroecology. In agreement with the present study, shell weights within the range between $4.02 \mathrm{gm}$ and $4.88 \mathrm{gm}$ were recorded by Halima (2007) in different indigenous ecotypes of Ethiopian chickens. In a study conducted on unimproved Horro chickens, Demissu (2020) observed the lowest shell weight in highland agroecology compared to the rest of the agroecology systems, which is in line with the findings of the current study.

Agroecology had no significant effect on the shell thickness of indigenous chicken eggs ( $>0.05$ ). In line with the present study, Fereja et al. (2016) reported $0.28 \pm 0.02 \mathrm{~mm}$ and $0.27 \pm 0.02 \mathrm{~mm}$ (mean $\pm \mathrm{SD})$ in highlands and midlands, respectively, and Serkalem (2019) reported $0.279 \pm 0.03 \mathrm{~mm}$ and $0.281 \pm 0.02 \mathrm{~mm}$ (mean $\pm \mathrm{SD}$ ) in lowlands and midlands, 
respectively, in different areas of Ethiopian indigenous chicken eggs. However, the result of Demissu (2020) $(0.35 \pm 0.06 \mathrm{~mm}, 0.36 \pm 0.06 \mathrm{~mm}$ and $0.37 \pm 0.07 \mathrm{~mm}$ (mean $\pm S D$ ) in the highlands, midlands and lowlands, respectively) was higher than the result of the current study. However, Yonas et al. (2019) reported a lower value $(0.19 \pm 0.06 \mathrm{~mm})$ than the present study on indigenous chickens in the Yirgalem district. Kgwatalala et al. (2016), Saroj et al. (2020), and Hussain (2013) recorded higher shell thickness values than those in the present study on indigenous chickens of Botswana, Nepal and Pakistan, respectively. In their study, they reported average shell thickness values of $0.39 \mathrm{~mm}$ and $0.39 \mathrm{~mm}$ and $0.53 \mathrm{~mm}$. Shell thickness is an important parameter that determines the internal quality of an egg. Internal egg contamination by microorganisms might be affected by the ability of eggshells to prevent the entrance of those microorganisms into the egg. Thick shells and firm interior parts (albumen and yolk) are accepted as being better in more successful hatching of embryos, especially from larger eggs (Narushin and Romanov, 2002).

There was a significant effect of agroecology on the shell percent of indigenous chicken eggs $(\mathrm{p}<0.05)$. It is highest in lowland agroecology but lowest in highland agroecology in the study areas. Demissu (2020) reported a higher shell percent on unimproved Horro chickens in all agroecologies than the results of the current study.

Table 2. External egg quality traits

\begin{tabular}{|c|c|c|c|c|}
\hline \multirow[t]{2}{*}{ Traits } & \multicolumn{3}{|c|}{ Agro-ecologies } & \multirow[t]{2}{*}{$p$ value } \\
\hline & Highland & Midland & Lowland & \\
\hline Egg weight (gm) & $42.89^{c}$ & $49.50^{\mathrm{a}}$ & $44.93^{b}$ & $<0.0001$ \\
\hline Egg length (mm) & $51.23^{\mathrm{c}}$ & $53.25^{\mathrm{a}}$ & $52.42^{\mathrm{b}}$ & $<0.0001$ \\
\hline Egg width (mm) & $37.36^{\mathrm{b}}$ & $38.65^{\mathrm{a}}$ & $38.62^{\mathrm{a}}$ & $<0.0001$ \\
\hline Shell weight (gm) & $3.70^{\mathrm{c}}$ & $4.38^{\mathrm{a}}$ & $4.12^{\mathrm{b}}$ & $<0.0001$ \\
\hline Shell thickness (mm) & $0.286^{\mathrm{a}}$ & $0.234^{\mathrm{b}}$ & $0.298^{\mathrm{a}}$ & $<0.0001$ \\
\hline Shape index & 72.96 & 72.78 & 73.76 & $<0.1422$ \\
\hline
\end{tabular}


$\begin{array}{lllll}\text { Shell percent } & 8.68^{\mathrm{b}} & 8.92^{\mathrm{ab}} & 9.26^{\mathrm{a}} & <0.0001\end{array}$

${ }^{a-c}$ Means within the row with different superscripts are significantly different $(p<0.05)$.

\section{Internal egg quality traits}

Internal egg quality traits at different agro-ecologies are presented in Table 14. There was a significant difference in the yolk height of indigenous chickens in different agroecology systems $(\mathrm{p}<0.05)$. Yolk highest is highest in highland agroecology and lowest in lowland agroecology. The results of the current study are in agreement with the findings of Yonas et al. (2019), who reported a mean yolk height value of $15.77 \mathrm{~mm}$ in Hawassa town and $15.90 \mathrm{~mm}$ in Yirgalem town. In line with the present study, average yolk heights of $15.9 \mathrm{~mm}$ and $15.2 \mathrm{~mm}$ were recorded for heavy ecotype and light ecotype Nigerian local chickens, respectively (Momoh, et al., 2010). Fisseha et al. (2010) reported a $15.1 \pm 1.3 \mathrm{~mm}$ mean value from local hens of Bure district, Ethiopia. His result is in good agreement with the findings of the current study. The result reported by Aberra (2018) is lower than the result of the current study. In his study, he reported average yolk height $(14.0 \pm 1.7 \mathrm{~mm})$ on local scavenging chickens in three districts of the Bench Maji Zone in southwestern Ethiopia. Similarly, Getnet et al. (2020) reported lower values (14.8 $\mathrm{mm}$ and $13.8 \mathrm{~mm}$ ) than the present study in local Horro and Tilil chicken ecotypes.

Albumen height shows higher value in highland than in midland and lowland agro-ecologies, but there is no significant difference in albumen height of eggs between midland and lowland agroecologies. In agreement with this, Halima (2007) reported a mean albumen height value between 4.23 and $4.95 \mathrm{~mm}$ in different local chicken ecotypes. A lower value $(3.4 \pm 0.7 \mathrm{~mm})$ was found in a study conducted on indigenous chickens reared under extensive management conditions in different districts of the Benchi maji Zone of southern Ethiopia (Welelaw 2018). This might occur due to the longer storage period and storage conditions of the eggs before analysis was conducted. Thus, albumen height is an indication of the freshness of eggs (Zeidler, 2002).

Significantly higher yolk weight was recorded in midland agroecology than in highland and lowland agroecology, but yolk weight was the same in both highland and lowland agroecology of the region. Halima (2007) and Demissu (2020) reported lower results, but Meseret (2010), Welelaw et al. (2018) and Ahmedin and Mangistu (2016) reported nearly similar results to those of the current study. The mean yolk weight value of 15.13 grams was recorded from a study 
conducted on Indigenous Sakini Chicken of Nepal (Saroj et al., 2020). A much lower yolk weight value of 9.667 grams was reported by the study of Nuhu et al. (2018) conducted on Nigerian indigenous chicken ecotypes. This difference can occur due to differences in genes and the environment.

Albumen weight shows significantly different values between all agro-ecologies. The highest albumen weight was measured midland, followed by lowland, and the lowest albumen weight was recorded in highland agroecology. Similarly, Halima (2007) recorded $23.52 \mathrm{~g}$ and $23.60 \mathrm{~g}$ of average egg weight for Tilil and Mecha indigenous chicken populations, respectively. Albumen weighing $22.30 \pm 0.25$ grams was reported in unimproved Horro chicken ecotypes, and this result is in agreement with the value of the current study (Demissu 2020).

There was no significant difference in yolk color, albumen ratio or yolk ratio among the different agro-ecologies of the region. The yolk color results in the current study are in agreement with the reports of Meseret (2010) and Yonas (2019). However, a lower result was revealed by Halima (2007), who reported Roch fan results between 3.00 and 4.00 for different indigenous chicken ecotypes under intensive management conditions. This implies that the difference in the production system has a high impact on the yolk color of eggs from indigenous chickens. The color of the egg yolk is mainly dependent on the type of ration and the management systems of the chickens. The eggs collected from scavenging birds have a higher yolk color count because scavenging birds have free access to green plants and other feed sources rich in xanthophylls (Zaman et al., 2004). According to a study conducted in Boricha District, the sidama regional state breed and agroecology showed significant differences in yolk color (Aberra et al., 2019). The value of yolk color is higher for indigenous chickens than for exotic chicken breeds. This might be due to indigenous chickens having a better scavenging ability to obtain greenish scavengeable feed resources that contain high amounts of xanthophylls. In agreement with the current study, Demissu (2020) reported 54.71\% and 34.99\% average albumin ratio and yolk ratio, respectively. A higher albumen ratio (75.373) and lower yolk ratio (26.747) were recorded in Nigerian indigenous chickens (Nuhu et al., 2018)

The Haugh unit and yolk index are significantly highest in the highland agroecology and lowest in the midland agroecology. A lower value of the Haugh unit was given by Welelaw et al. (2018), Halima (2007) and Meseret (2010), but a nearly similar result was reported by Yonas 
(2019) on Ethiopian indigenous chickens and Momoh et al. (2010) on Nigerian indigenous chicken ecotypes. Saroj et al. (2020) reported 74.46 Haugh unit value for indigenous chickens of Nepal. A higher value of the Haugh unit (100.533) was recorded in a study performed on indigenous chickens of Nigerian savanna (Nuhu et al., 2018).

There were differences in the yolk diameter of indigenous chickens among all agro-ecologies of the Sidama region. Yolk diameter is highest in midland followed by lowland and lowest in highland agroecology. In agreement with the current study, Demissu (2020) reported yolk diameter values of unimproved Horro chickens of $36.6 \mathrm{~mm}, 41.1 \mathrm{~mm}$ and $39.7 \mathrm{~mm}$ (p value $<0.001)$ in highland, midland and lowland agroecologies, respectively.

Table 3. Internal egg quality traits

\begin{tabular}{lllll}
\hline Traits & \multicolumn{2}{l}{ Agro-ecology } & p value \\
\cline { 2 - 4 } & $\begin{array}{l}\text { Highland } \\
(\text { Mean } \pm \text { SD })\end{array}$ & $\begin{array}{l}\text { Midland } \\
(\text { Mean } \pm S D)\end{array}$ & $\begin{array}{l}\text { Lowland } \\
(\text { Mean } \pm S D)\end{array}$ & \\
\hline Yolk height $(\mathrm{mm})$ & $16.80^{\mathrm{a}} \pm 1.10$ & $15.70^{\mathrm{c}} \pm 1.31$ & $16.17^{\mathrm{b}} \pm 2.24$ & $<0.0001$ \\
Albumen height $(\mathrm{mm})$ & $6.26^{\mathrm{a}} \pm 1.03$ & $4.96^{\mathrm{b}} \pm 1.20$ & $4.96^{\mathrm{b}} \pm 0.94$ & $<0.0001$ \\
Yolk weight $(\mathrm{gm})$ & $16.02^{\mathrm{b}} \pm 2.32$ & $17.86^{\mathrm{a}} \pm 1.96$ & $16.52^{\mathrm{b}} \pm 2.04$ & $<0.0001$ \\
Albumen weight $(\mathrm{gm})$ & $21.78^{\mathrm{c}} \pm 3.16$ & $25.47^{\mathrm{a}} \pm 3.39$ & $23.49^{\mathrm{b}} \pm 4.25$ & $<0.0001$ \\
Yolk color $(\mathrm{R} / \mathrm{Scale})$ & $9.35 \pm 1.49$ & $9.46 \pm 1.78$ & $8.96 \pm 1.80$ & 0.1006 \\
Yolk ratio & $37.68 \pm 6.72$ & $36.17 \pm 3.92$ & $37.30 \pm 6.28$ & 0.1697 \\
Albumen ratio & $51.35^{ \pm} \pm 9.75$ & $51.48 \pm 6.19$ & $52.94 \pm 10.66$ & 0.4033 \\
Haugh unit & $84.23^{\mathrm{a}} \pm 6.73$ & $71.86^{\mathrm{c}} \pm 9.79$ & $74.44^{\mathrm{b}} \pm 7.29$ & $<0.0001$ \\
Yolk index & $43.84^{\mathrm{a}} \pm 3.99$ & $37.67^{\mathrm{c}} \pm 5.18$ & $40.76^{\mathrm{b}} \pm 3.56$ & $<0.0001$ \\
Yolk diameter & $38.47^{\mathrm{c}} \pm 2.49$ & $41.40^{\mathrm{a}} \pm 2.09$ & $39.75^{\mathrm{b}} \pm 1.79$ & $<0.0001$ \\
\hline
\end{tabular}

${ }^{a-c}$ The means in rows with different superscript letters are significantly different $(p<0.05)$

\section{Phenotypic correlation among internal and external egg quality traits}

\section{Phenotypic correlation among external egg quality traits}

The phenotypic correlation of the external egg quality traits of indigenous chicken eggs is presented in Table 4. The results indicated that there was a positive and strong correlation between egg weight and egg length, egg weight and egg width, egg weight and shell weight, egg weight and surface area of the egg. In line with the present study, Markos et al. (2017) reported 
that egg weight has a strong positive correlation with shell weight, egg length and egg width in indigenous chicken ecotypes of Tigray. Similarly, Kgwatalala et al. (2016), on dwarf, normal and necked neck strains of Tswanan chickens, and Sezai et al. (2014), on Partridge (Alectoris Chukar), reported that there was a high positive correlation of egg weight with egg width, egg length and shell weight of different poultry species. Egg weight is negatively correlated with shell thickness and shell percentage. This result is in agreement with the reports of Udoh et al. (2012), Kgwatalala et al. (2016), Sezai et al. (2015) and Okon et al. (2020). However, disagreement was reported by Cahyadi et al. (2019) and Zhang et al. (2005) on Japan's Quills and brown egg dwarf layers, respectively.

There was a positive and strong correlation between egg length and egg width. Bobbo et al. (2013) reported a strong positive correlation between egg length and egg width on frizzle and necked neck indigenous chickens of Yola. Both egg length and egg width were positively and strongly correlated with shell weight and surface area. Reports in agreement with the current study were revealed by Sezai et al. (2015) and Bobbo et al. (2013) on different poultry species. No significant positive correlation was reported between egg length and shell weight or between egg width and shell weight in three different strains of Tswanan chickens (Kgwatalala et al., 2016). Egg length is highly negatively correlated with the shape index, but egg width and shape index are strongly positively correlated with each other. This indicates that when the egg becomes wider, its shape index will be larger, and it will possess a round shape that makes it difficult to handle and package. Similarly, a strong negative correlation between egg length and shape index and a strong positive correlation between egg width and shape index were shown in dwarf, normal and necked neck indigenous chickens of Tswana (Kgwatalala et al., 2016).

Shell weight has a strong positive correlation with shell percentage and egg surface area. Sezai et al. (2015), Markos et al. (2017) and Islam and Dutta (2011) reported a significant positive correlation between shell weight and shell ratio in different poultry species. Shell percentage is defined as the ratio of shell weight to total egg weight, so that the amount of shell weight increases then higher will be shell percentage.

Shell percentage has a strong negative correlation with egg weight and surface area. In agreement with the current study, Bertha (2013) reported a significant negative correlation between shell ratio and egg weight on Cobb 500 broiler hatching eggs. However, the report of 
Olawumi and Ogunlade (2008) is the reverse of the current study; they reported a nonsignificant positive correlation between shell ratio and egg weight in exotic Isa brown layer breeders. Additionally, there was a nonsignificant negative correlation between shell percentage and egg length and between shell percentage and egg width. This result is in agreement with the results of Sezai et al. (2015) and Markos et al. (2017).

Table 4. Phenotypic correlation among external egg quality parameters

\begin{tabular}{|c|c|c|c|c|c|c|c|}
\hline & $\begin{array}{l}\text { Egg } \\
\text { weight }\end{array}$ & $\begin{array}{l}\text { Egg } \\
\text { length }\end{array}$ & Egg width & $\begin{array}{l}\text { Shell } \\
\text { weight }\end{array}$ & $\begin{array}{l}\text { Shell } \\
\text { thickness }\end{array}$ & $\begin{array}{l}\text { Shape } \\
\text { index }\end{array}$ & $\begin{array}{l}\text { Shell } \\
\text { percentag } \\
\text { e }\end{array}$ \\
\hline Egg weight & 1 & & & & & & \\
\hline Egg length & $0.645^{* *}$ & 1 & & & & & \\
\hline Egg width & $0.692^{* *}$ & $0.443^{* *}$ & 1 & & & & \\
\hline $\begin{array}{l}\text { Shell } \\
\text { weight }\end{array}$ & $0.326^{* *}$ & $0.272^{* *}$ & $0.315^{* *}$ & 1 & & & \\
\hline $\begin{array}{l}\text { Shell } \\
\text { thickness }\end{array}$ & $-0.187^{* *}$ & $-0.148^{* *}$ & -0.024 & 0.036 & 1 & & \\
\hline $\begin{array}{l}\text { Shape } \\
\text { index }\end{array}$ & -0.021 & $-0.606^{* *}$ & $0.439^{* *}$ & 0.015 & 0.128 & 1 & \\
\hline $\begin{array}{l}\text { Shell } \\
\text { percentage }\end{array}$ & $-0.367^{* *}$ & $-0.181^{* *}$ & $-0.172^{* *}$ & $0.752^{* *}$ & $0.164^{* *}$ & 0.029 & 1 \\
\hline $\begin{array}{l}\text { Surface } \\
\text { area }\end{array}$ & $0.999^{* *}$ & $0.646^{* *}$ & $0.693^{* *}$ & $0.327^{* *}$ & -0.188 & -0.021 & $-0.368^{* *}$ \\
\hline
\end{tabular}

$*: \mathrm{p}<0.05, * *: \mathrm{p}<0.01$

\section{Phenotypic correlation among internal egg quality traits}

The phenotypic correlations among internal egg quality traits are shown in Table 5. The results indicated that there was a strong and positive correlation between albumen weight and yolk weight and between albumen weight and yolk diameter. This result disagrees with the result of Bertha (2013), who reported that there is a negative correlation between albumen weight and yolk weight and yolk diameter. Markos et al. (2017) reported a strong positive correlation between albumen weight and yolk weight in highland midland and lowland ecotypes of Tigray chickens. A strong positive correlation between albumen weight and yolk weight was reported in 
dwarf, normal and necked neck indigenous chickens of Tswana (Kgwatalala et al., 2016). This result is in agreement with the findings of the current study.

Albumen height is strongly positively correlated with the Haugh unit. In agreement with the current study, Bobbo et al. (2013) reported correlation values between albumen height and Haugh units of $0.98,0.91$ and 0.90 for frizzle, necked neck and smooth feathered indigenous chickens, respectively, in Adamawa state of Yola. Additionally, this result is in agreement with the findings of Alipanah et al. (2013), Olawumi and Ogunlade (2008), Bertha (2013), Markos et al. (2017). This value is an indication that the Haugh unit of egg is highly dependent on the albumen height. Albumen height is higher for fresh eggs and deteriorates with increasing storage period and storage temperature. At the same time, the Haugh unit of eggs decreased. Albumen height was significantly positively correlated with egg yolk height. This finding is in agreement with the results of Bertha (2013) and Olawumi and Ogunlade (2008). However, a nonsignificant negative correlation was reported between albumen height and yolk height for local barred hens of Cameroon (Mube et al., 2014). However, there was a strong negative correlation between albumen height and yolk diameter. Bobbo et al. (2013) reported a strong positive correlation between albumen height and yolk height for necked neck indigenous chickens, but in a similar study, he reported a negative nonsignificant correlation between albumen weight and yolk weight for frizzle and smooth feathered indigenous chickens of Yola. These differences in egg qualities might occur due to different factors, such as storage, strain and age of hens, induced molt, nutrition and disease (Roberts. 2004).

Yolk weight was positively correlated with yolk diameter and strongly negatively correlated with the yolk index. This implies that as yolk weight increases, yolk diameter also increases. This result is consistent with the report of Markos et al. (2017). However, the results of the current study disagree with the findings of Okon et al. (2020), who reported a value of -0.296 between yolk weight and yolk diameter. Additionally, there was a negative correlation between yolk weight and Haugh units. This result agrees with the reports of Olawumi and Ogunlade (2008) and Bertha (2013).

There was a strong positive correlation between yolk height and Haugh units. Different scholars have reported similar findings to the current study (Markos et al., 2017, Olawumi and Ogunlade 2008 and Bertha 2013). This implies that yolk height and albumen height go in the parallel 
direction. When we opened the egg during our study, the first indications of its quality were both albumen height and yolk height. If the egg was stored for a long time, albumen and yolk expanded suddenly as the egg was opened, then measurements of both albumen height and yolk height decreased. Yolk diameter is strongly negatively correlated with the yolk index and Haugh unit. Sezai et al. (2015) reported that yolk diameter has a strong negative correlation with the yolk index and a nonsignificant negative correlation with the Haugh unit. This might occur because when yolk height decreases due to different factors, yolk expands, and its diameter increases. The yolk index and Haugh unit are strongly positively correlated with each other. This result is in agreement with findings reported by Ojedapo (2013) and Bobbo et al. (2013). These two parameters are related to yolk height and albumen height. As discussed above, when albumen height decreases due to different factors, yolk height also decreases, and the same is true for the yolk index and Haugh unit.

Table 5. Phenotypic correlation among internal egg quality traits

\begin{tabular}{|c|c|c|c|c|c|c|c|}
\hline & A/weight & A/height & Y/weight & Y/height & Y/diameter & Y/index & $\begin{array}{l}\text { Haugh } \\
\text { unit }\end{array}$ \\
\hline $\mathrm{A} /$ weight & 1 & & & & & & \\
\hline A/height & -0.04249 & 1 & & & & & \\
\hline $\begin{array}{l}\text { Yolk } \\
\text { weight }\end{array}$ & $0.37739^{* *}$ & $-0.14792^{*}$ & 1 & & & & \\
\hline $\begin{array}{l}\text { Yolk } \\
\text { height }\end{array}$ & 0.07297 & $0.51757^{* *}$ & 0.09330 & 1 & & & \\
\hline $\begin{array}{l}\text { Yolk } \\
\text { diamet }\end{array}$ & $0.34960^{* *}$ & $-0.23178^{* *}$ & $0.57340^{* *}$ & -0.11301 & 1 & & \\
\hline Yolk index & -0.09492 & $0.48481^{* *}$ & $-0.25472^{* *}$ & $0.78193^{* *}$ & $-0.60384^{* *}$ & 1 & \\
\hline Haugh unit & $-0.12347^{*}$ & $0.96261^{* *}$ & $-0.18928^{* *}$ & $0.52967^{* *}$ & $-0.28406^{* *}$ & $0.51693^{* *}$ & 1 \\
\hline
\end{tabular}




\section{Phenotypic correlations between some internal and external egg quality traits}

Phenotypic correlations between external and internal egg quality traits are presented in Table 6. The results of the current study show that albumen height has a statistically significant negative correlation with egg weight, egg length, egg width and shell weight $(\mathrm{p}<0.01)$. In agreement with the current study, Bertha (2013) reported a significant negative correlation of albumen height with egg weight, egg length, egg width and shell weight. There was a slight positive correlation between albumen height and shell thickness ( $\mathrm{p}>0.05)$. Godson et al. (2020) found a positive correlation between albumen height and shell thickness. This implies that albumen height can be affected by shell strength because a thicker shell has better resistance to temperature and can control the entry of microorganisms inside the egg. Then, albumen height remained high for a longer time than eggs with thinner shells.

The correlation of albumen weight with egg weight, egg length, egg width and shell weight was positive and statistically significant $(\mathrm{p}<0.01)$. These findings were supported by Olawumi and Ogunlade (2008), Bertha (2013), Kul and Seker (2004), and Markos et al. (2017). Albumen weight was significantly and negatively correlated with shell thickness ( $>0.05)$. This result is in agreement with the findings of Kul and Seker (2004). There was a statistically nonsignificant positive correlation between albumen weight and shape index $(\mathrm{p}>0.05)$. This finding was supported by Sezai et al., (2013). However, disagreement was reported on scavenging indigenous chickens of Zambia by Rifu et al. (2020), who reported a strong negative correlation between albumen weight and shape index.

Haugh unit had a strong negative correlation with egg weight, egg length, egg width and shell weight $(\mathrm{p}<0.01)$. This happened due to the strong negative correlation of albumen height with these parameters. This result disagrees with the findings of Kul and Seker (2004) and (Bertha 2013). In agreement with the current study, the findings of Alipanah et al. (2013) and Godson et al. (2020) revealed that there is a strong negative correlation between the Haugh unit and shell weight of eggs.

Yolk height had a negative but nonsignificant correlation with external egg quality parameters that were observed in this study ( $\mathrm{p}>0.05$ ). Godson et al. (2020) reported a positive correlation of yolk height with egg weight, egg length and egg width. In a similar study, he reported a negative correlation of yolk height with shell weight, shell thickness and shape index, which is in parallel 
with the findings of the current study. In contrast to the findings of the current study, Bertha (2013) found a strong positive correlation of yolk height with egg weight, egg length, egg width and shell weight of Cobb500 broiler hatching eggs.

Yolk diameter had a strong positive correlation with egg weight, egg length, egg width and shell weight $(p<0.01)$. This result is in agreement with the findings of Kul and Seker (2004) and Rifu et al. (2020). However, there was a slight negative correlation of yolk diameter with shell thickness and shape index $(\mathrm{p}>0.05)$.

Yolk weight had a strong positive correlation with egg weight, egg length and egg width ( $\mathrm{p}<0.01)$. This result was supported by Kul and Seker (2004), Markos et al. (2017), and Rifu et al. (2020). According to these findings, including the current study, yolk weight increases with increasing external parameters. Egg weight, length and width increase with different factors, such as the age of the hen, breed and strain, nutrition and other environmental factors. At the same time, the weight of the egg increased.

The yolk index had a significant negative correlation with egg weight, egg length, egg width and shell weight $(\mathrm{p}<0.01)$. This result disagrees with the findings of Rifu et al. (2020) and Bertha (2013). There was a slight positive correlation between the yolk index and shell thickness and the shape index ( $p>0.05)$. In line with the present study, Godson et al. (2020) showed a slight positive correlation between the yolk index and shell thickness. The finding of Rifu et al. (2020) agrees with the results of the current study on the correlation between the yolk index and shape index.

Table 6. Phenotypic correlation between external and internal egg quality traits

\begin{tabular}{lllllll}
\hline & Egg weight & Egg length & Egg width & Shell weight & $\begin{array}{l}\text { Shell } \\
\text { thickness }\end{array}$ & $\begin{array}{l}\text { Shape } \\
\text { index }\end{array}$ \\
\hline $\begin{array}{l}\text { Albumen } \\
\text { height }\end{array}$ & $-0.172^{* *}$ & $-0.138^{* *}$ & $-0.209^{* *}$ & $-0.237^{* *}$ & 0.028 & -0.053 \\
$\begin{array}{l}\text { Albumen } \\
\text { weight }\end{array}$ & $0.365^{* *}$ & $0.279^{* *}$ & $0.223^{* *}$ & $0.161^{* *}$ & $-0.134^{*}$ & 0.012 \\
\end{tabular}




$\begin{array}{lllllll}\begin{array}{l}\text { Haugh } \\ \text { unit }\end{array} & -0.248^{* *} & -0.183^{* *} & -0.245^{* *} & -0.285^{* *} & 0.074 & -0.063 \\ \begin{array}{l}\text { Yolk } \\ \text { height }\end{array} & -0.081 & -0.056 & -0.091 & -0.157 & -0.033 & -0.043 \\ \begin{array}{l}\text { Yolk } \\ \text { diameter }\end{array} & 0.441^{* *} & 0.291^{* *} & 0.318^{* *} & 0.296^{* *} & -0.177^{* *} & 0.051 \\ \begin{array}{l}\text { Yolk } \\ \text { weight }\end{array} & 0.341^{* *} & 0.377^{* *} & 0.232^{* *} & 0.190^{* *} & -0.136^{*} & 0.037 \\ \text { Yolk } & -0.284^{* *} & -0.284^{* *} & -0.214^{* *} & -0.286^{* *} & 0.088 & 0.002 \\ \text { index } & & & & & & \end{array}$

${ }^{*}: \mathrm{p}<0.05,{ }^{* *}: \mathrm{p}<0.01$

\section{Conclusion}

The results show that agroecology has no effect on the fertility and hatchability of indigenous chickens. Eggs collected from midland agroecology had the highest egg weight, egg length, egg width and shell weight, followed by those collected from lowland agroecology. However, agroecology has no effect on the shape index of indigenous chicken eggs. Eggs collected from midland showed superior yolk weight, albumen weight and yolk diameter. However, eggs collected from highlands showed the highest yolk height, albumen height, yolk index and Haugh unit values. Agroecology has no effect on the yolk color of indigenous chicken eggs. Therefore, it can be concluded that midland agroecology is more favorable for external and internal egg quality of indigenous chickens when stored for a short period of time, but eggs remain fresh for a longer time in highland agroecology.

\section{References}

Aberra M, Zemene W, Yoseph T. Assessiment of prevailing handling and egg quality from scavenging local chickens reared in different agroecological zones of Ethiopia. Res Jour poult Sci. 2012; 5: 64-70 
Addisu H, Hailu M, Zewdu W. Local Chicken Production System and Breeding Practice in North Wollo, Amhara Region, Ethiopia. Poult, Fish and Wild Sci. 2013; 1: 108.

Adeogun I. O, Amole F. O. Some quality parameters of exotic chicken eggs under different storage conditions. Bull Ani Heal and Prod Afri. 2004; 52: 43-47.

Ahmedin A, Mangistu U. Evaluation of Fertility, Hatchability and Egg Quality of Rural Chicken in Gorogutu District, Eastern Hararghe, Ethiopia. As Jour Poult Sci. 2016; 10: 111-116.

Alewi M, Melesse A, Teklegiorgis Y. Crossbreeding Effect on Egg Quality Traits of Local Chickens and Their F1 Crosses With Rhode Island Red and Fayoumi Chicken Breeds Under Farmers’ Management Conditions. Jour Ani Sci Adv. 2012; 2(8):697-705.

Alipanah M, Deljo J, Rokouie M, Mohammadnia R. Heritability and genetic and phenotypic correlations of egg quality traits in Khazak Layers. Trak Jour Sci. 2013; 2:175-180.

Bain M. Recent advances in the assessment of eggshell quality and their future application. Worl Poult Sci Jour. 2005; 61: 268-277.

Bertha A. Phenotypic correlation estimates of external and internal quality traits of cobb500 broiler hatching eggs. MSc. thesis. Kwame Nkrumah University of Science and Technology, Kwame Nkrumah, Kumasi. 2013.

Bobbo A, Baba S, Yahaya M. Egg quality characteristics of three phenotypes of local chickens in Adamawa State. Jour Agri Vet Sci (IOSR-JAVS) 2013; 4(2):13-21.

Cahyadi M, Fauzy R, Dewanti R. Egg Production Traits and Egg Quality Characteristics in Black and Brown Plumage Color Lines of Japanese Quai. Poult Sci Jour. 2019; 7(2):179-184.

Demissu H. Evaluation of productive and reproductive performances of different strains of chickens under varied management systems in western Ethiopia. PhD Dissertation. Addis Ababa University. Addis Ababa, Ethiopia. Ref no. 052/01/2020. 2020

Desalew T. Management practices, productive performances and egg quality traits of exotic chickens under village production system in East Shewa, Ethiopia. MSc thesis, Addis Ababa University. Bishoftu, Ethiopia. 2012 
Dudusola I. Comparative evaluation of internal and external qualities of eggs from quail and guinea fowl. Int Res Jour Plant Sci. 2010; 1: 112-115.

FAO. Poultry Sector Ethiopia. FAO Animal Production and Health Livestock Country Reviews. No. 11. Rome. 2019

Farooq, M., Mian, M.A. Ali, M., Durranim F.R., Asquar, A. \& Muqarrab, A.K.. Egg traits of Fayoumi bird under subtropical conditions. Sar Jour Agri. 2001; 17: 141-145.

Fereja B, Bikila N, Mengistu U, Negassi A. The study of egg quality on chicken village In Chelliya district Western Shoa, Ethiopia. Int Jour Res - GRANTHAALAYAH 2016; 4(2):46-51.

Fisseha M, Azage T, Tadelle D. Local chicken production and marketing systems in Ethiopia: Characteristics and opportunities for market-oriented development. IPMS (Improving Productivity and Market Success) of Ethiopian Farmers Project Working Paper 24. Nairobi, Kenya, ILRI. 2010

Galobart J, Sala R, Rincon-Carruyo X, Manzanilla G, Vila B, Gasa J. Egg yolk color as affected by saponification of different natural pigmenting sources. J. Appl. Poult. Res. 2004; 13:328-334.

Gebreegziabher Zereu and Tsegay Lijalem. Production and reproduction performance of local chicken breeds and their marketing practices in the Wolaita Zone, southern Ethiopia. Afr Jour Agri Res. 2016; 11(17): 1531-1537.

Gerber G. Factors affecting egg quality in commercial laying hens. A review. Availablefrom:http://]eggfarmers.org.nz/eggfarmers/wpcontent/uploads/2012/04/factors_affectin g_egg_quality.pdf. 2012

Getnet Z, Mengistu U, Getachew A, Wondmeneh E, Tadelle D. Comparative Laying Performance, Egg Quality, Fertility and Hatchability of Guinea Fowl with Tilili, Horro and Potchefstroom Koekoek Chicken Breeds. Open Journal of Animal Sciences 2020; 10: 665-682.

Godson A, Gabriel A-A, Mark Ewusi S, Theresah N, David A. Correlation Between Egg Weight and Egg Characteristics in Japanese Quail. Animal and Veterinary Sciences 2020; 8(3): 51-54.

Grignon D. Optimal Egg Shell Quality: Nutrition Essentials. Hendrix Genetics. 2016. 
Haugh R. The Haugh unit for measuring egg quality. US Egg Poult Mag. 1937; 43:522-555, $572-573$.

Halima H M. Phenotypic and genetic characterization of local chicken populations in Northwest Ethiopia. PhD dissertation, University of the Free State, Bloemfontein, South Africa. 2007

Helmenstine A M. "How to Change Egg Yolk Color." ThoughtCo, thoughtco.com/how-tochange-egg-yolk-color 2020; 607441.

Hussain S, Ahmed Z, Khan M.N, Khan A. A study on quality traits of chicken eggs collected from different areas of Karachi. Sarh Jour Agri. 2013; 29(2): 255-259

Isidahomen C E, Njida A A, Olatunji E A. Egg Quality Traits of Local and Exotic Chickens As Influenced By Specific Genes. Jour Bio Agri Heal. 2013; 3(1).

Islam S, Dutta K. Egg quality traits of local, exotic and crossbred chickens (gallus domesticus 1.) in Rajshahi, Bangladesh. Jour Lif Earth Sci. 2011; 5:63-67.

Islam AM, Bulbul S.A, Seeland G, Islam A.B. Egg quality of different chicken genotypes in summer and winter. Park Jour Bio Sci. 2001; 4: 1411-1414.

Kgwatalala P.M., Molapisi M., Thutwa K., Sekgopi B., Selemoge T.P. and Nsoso S.J.. Egg quality characteristics and phenotypic correlations among egg quality traits in the naked neck, normal and dwarf strains of Tswana chickens raised under intensive management system. Int Jour Env Agri Res. 2016; 2(8):96-105.

Khatkar M.S, Sandhu J.S, Brah G.S, Chaudhary M. L. Genetic analysis of egg shell quality characters in layer chicken. Ind Jour Ani Sci, 1994; 64:1248-1253.

King'or A.M.. Review of the factors that influence egg fertility and hatchability on poultry. Int Jour Poult Sci. 2011; 6(1): 483-492.

Kocevski D. The influence of strain and age on some egg quality parameters of commercial laying hens. Biotech Ani Husb. 2011; 27: 1649-1658.

Kul S, Seker I. Phenotypic correlations between some external and internal egg quality traits in the Japanese quail (Coturnix coturnix japonica). Int Jour Poult Sci. 2004; 3: 400-405. 
Lundberg C-A, Vaisanen R A. Selective correlation of egg size with chick mortality in the blackheaded gull (LARUS RIDIB). 1979.

Markos S, Birhanu B, Astatkie T. Evaluation of egg quality traits of three local chicken ecotypes kept under farmers' management conditions. Int Jour Poult Sci. 2017; 16: 180-188.

Madalena L, Joana C, Audia M, Cordovil S, Susana P. Alves, Rui J. Bessa B, In^es Carolinoz. Comparison between the quality of eggs from local chicken breeds and that from commercial layers. Poult Sci. 2019; 99:1768-1776.

Mbuthia P, Njagi W, Nyaga N, Bebora C, Mugera M, Minga U, Olsen E. Hatchability and fertility of local chicken and duck eggs, and some causes of chick and duckling mortality in Kenya. Ken Veter. 2007; 31(1): 6-13.

Meseret M. Characterization of village chicken production and marketing system in gomma wereda, Jimma Zone, Ethiopia. MSc thesis. Jimma, Ethiopia. 2010.

Mohammed M. D, Abdalsalam Y.I, Kheir A.M, Jin-yu W, Hussein M. H. Comparison of egg characteristics of different Sudanese Indigenous chicken types. Int Jour Poult Sci. 2005; 4(7): $455-457$.

Momoh O.M, Ani A.O, Ugwuowo L.C.. Part-period egg production and egg quality characteristics of two ecotypes of Nigerian local chicken and F1 crosses. Int Jour Poult Sci. 2010; 9(8):744-748.

Monira K.N, Salahuddin M, Miah G. Effect of breed and holding period on egg quality characteristics of chicken. Int Jour Poult Sci. 2003; 2: 261-263.

Mube H K, Kana J R, Tadondjou C D, Yemdjie D D M, Manjeli Y, Teguia A. Laying performances and egg quality of local barred hens under improved conditions in Cameroon. Jour Appl Biosci. 2014; 74:6157-6163.

Mueller W. J, Maw A. G, Buss, E. G. The influence of season and the age of layers on egg weight shape index, albumen quality and shell thickness. Poult Sci. 1960; 39 (4), 854-860. 
Narushin V.G, Romanov M.N. Egg physical characteristics and hatchability. Worl Poult Sci Jour. 2002; 58: 297-303.

Nedeljka N, Kocevski D. Forming egg shape index as influenced by ambient temperatures and age of hens. Biotech Ani Husb. 2006; 22 (1-2): 119-125.

Nigussie D. Breeding programs for local chicken in Ethiopia. Analysis of diversity in production systems and chicken population. $\mathrm{PhD}$ thesis, Wageningen University, The Netherlands. ISBN: 978-90-8585-872-0. 2011.

Nuhu B. T, Adelanwa M. A, Hassan M. R, Duru S. Egg quality parameters and blood biochemical profile of six strains of poultry under extensive management system in Nigerian savanna. Nig Jour Ani Sci. 2018; 20(1):72-80.

Nure H. D. Evaluation of artificially incubated local chicken. Lamb Acad Pub. 28. 2018

Ojedapo L.O. Phenotypic correlation between the external and internal egg quality traits of pharaoh quail reared in derived Savanna Zone of Nigeria. Jour Bio Agri Healthcare. 2013; 3(10):80-83.

Okon B, Ibom LA, Dauda A, Ebegbulem VN. Egg quality traits, phenotypic correlations, egg and yolk weights prediction using external and internal egg quality traits of Japanese quails reared in Calabar, Nigeria. Int Jour Mole Bio. 2020; 5(1):21-26.

Olawumi S.O, Ogunlade J.T. Phenotypic correlation between some external and internal egg quality traits in the Isa Brown Layer Breeders. As Jour Poult Sci. 2008; 2(1):30-35.

Rajkumar U, Sharma R.P, Rajaravindra K.S, Niranjan M, Reddy B.L.N, Bhattacharya T.K. Chatterjee R.N. Effect of genotype and age on egg quality traits in naked neck chickenunder tropical climatefromindia. Int Jour Poult Sci. 2009; 8:1151-1155.

Rifu XU, Simushi Liswaniso and Ning Qin. Quantitative analysis of egg quality traits of local free-range chickens in Kabwe, Zambia. Jour Entom Zool Stud. 2020; 8(2):603-608.

Roberts J R. Factors affecting egg internal quality and egg shell quality in laying hens. Jour Poult Sci. 2004; 41(3): 161-167. 
Sapp R.L, Rekaya R, Misztal I, Wing T. Male and female fertility and hatchability in chickens: A longitudinal mixed model approach. Poult Sci. 2004; 83: 1253-156.

Sarica M. Erensayin C. Poultry Products. In: TURKOGLU M., M. SARICA: Poult Sci. BeyOfset, Ankara, Turkey, 2009; 89-138.

Saroj S, Mana Raj K, Naba Raj D, Neena A G, Nirajan B. Evaluation of External and Internal Egg Quality Traits of Local Sakini Chicken in Different Generations of Selection. Int Jour Agri Forest. 2020; 10(2): 41-48.

SAS. Statistical Analysis System, version 9, Institute, Inc., Cary, NC, USA. 2002.

Sekeroglu A, Altuntas E. Effects of egg weight on egg quality characteristics. Jour Sci Food Agri. 2009; 89(3): 379-383.

Serkalem A, Aberra M, Sandip B. Egg Production and Egg Quality Traits of Local and Exotic Chicken Breeds Reared in Two Agroecologies under Traditional Management System. Res Jour Fo Nut. 2019; 3: 11-17.

Sezai A, Aşkın G, Taki K, Kemal K. Effects of egg weight on egg quality traits in partridges (AlectorisChukar). Journal of Applied Animal Res. 2015; 43(4):450-456. DOI: 10.1080/09712119.2014.980419

Silversides F. G, Korver D. R, Budgell K. L. Effect of layer strain and age at photostimulation on egg production, egg quality and bone strength. Poult Sci. 2006; 85: 1136-1144.

Song K. T. A Comparison of egg quality of Pheasant, Chukar, Quail and Guinea fowl. Asian Aust Jour Ani Sci. 2000; 13: 986-990.

Tadelle D. Phenotypic and genetic characterization of local chicken ecotypes in Ethiopia. 2003

Udoh U.H, Okon B, Udoh A.P.. Egg quality characteristics, phenotypic correlation and prediction of egg weight in three (necked neck, frizzled feathered and normal feathered Nigerian chicken). Int Jour Poult Sci. 2012; 11(11):696-699.

Van den Brand H, Parmentier H. K, Kemp B. Effects of housing system (outdoor vs. cages) and age of laying hens on egg characteristics. Brit Poult Sci. 2004; 45:745-752. 
Veena D, Eswara Rao B, Naga Mallika E, Azad K. A study on the quality traits of chicken eggs collected in and around Gannavaram, Krishna district, in different seasons. Int Jour Rec Scient Res 2015; 6(9): 6487-6489.

Vuilleumier P. The Roche yolk color fan.An instrument for measuring yolk color. Poult Sci. 1968; 48:767-778.

Welelaw E, Aberra M, Mohammed B, Mestawet T. Assessing the Performance, Egg Quality, and Carcass Characteristics of Local Chickens Reared Under Traditional Management System" Int Jour Res Stud Agri Sci. (IJRSAS). 2018; 4(10): 27-35.

Yassin H, Velthuis A G J, Boerjan M, van Riel J, Huime R B M. Production, modeling, and education: Field study on broiler eggs hatchability. Poult Sci. 2008; 87: 2408-2417 http://ps.fass. Org/cgi/reprint/87/1 1/2408

Yonas K, Sandip B, Mestawet T. Some internal and external egg quality characteristics of local and exotic chickens reared in Yirgalem and Hawassa towns, Ethiopia. Int Journ Lives Prod. 2019; 10(5): 135-142.

Zaman M, Sorensen P, Howlider M. Egg production performance of a breed and three crossbreds under a semiscavenging system of management. Lives Res Rur dev. 2004; 16(8).

Zeidler G. Shell egg quality and preservation. In: Commercial chicken meat and egg production, 5th edition, Kluwer academic publishers, Massachusetts, USA. 2002.

Zhang C, Ning H, Xu Y, Hou C, Yang N. Heritability and Genetic and Phenotypic Correlations of Egg Quality Traits in Brown-Egg Dwarf Layers. Poult Sci. 2005; 84:1209-1213.

Zita L, Tůmová E, Štolc, L. Effects of genotype, age and their interaction on egg quality in brown-egg laying hens. Acta Vet. Brno 2009; 78:85-91. 


\section{Declaration}

Ethical approval and consent to participate

Eggs used for current study were collected from farmers. During the collection of eggs, care was taken as much as necessary. During and after chicks hatched, the right of animals was considered.

Consent for publication: not applicable.

Availability of data and materials

The data set generated during and/or analyzed during current study are not publicly available to prevent any improper use of data by someone else. but are available from the corresponding author on reasonable request.

Competing interests

The authors declare that they have no competing interests

Funding

The source of fund for current study to purchase experimental units and to collect data is SARI (Southern Agricultural Research Institute).

Authors' contribution

The main author of current study Legesse Tunsisa conducted data collection, analysis, interpretation, writing up of this manuscript.

Co-author of current study Kefiyalew Berihun was participated in guidance and editing, reading and approving this manuscript.

Acknowledgement

The authors of this manuscript would like to acknowledge Meseret Girma ( $\mathrm{PhD})$, Mestawet Taye $(\mathrm{PhD})$ and Mr. Kibru Beriso for their evaluation and approval of this manuscript. Our friends Birhanu Bekele and Sidrak Sintayehu, your gratitude is over the words. 
